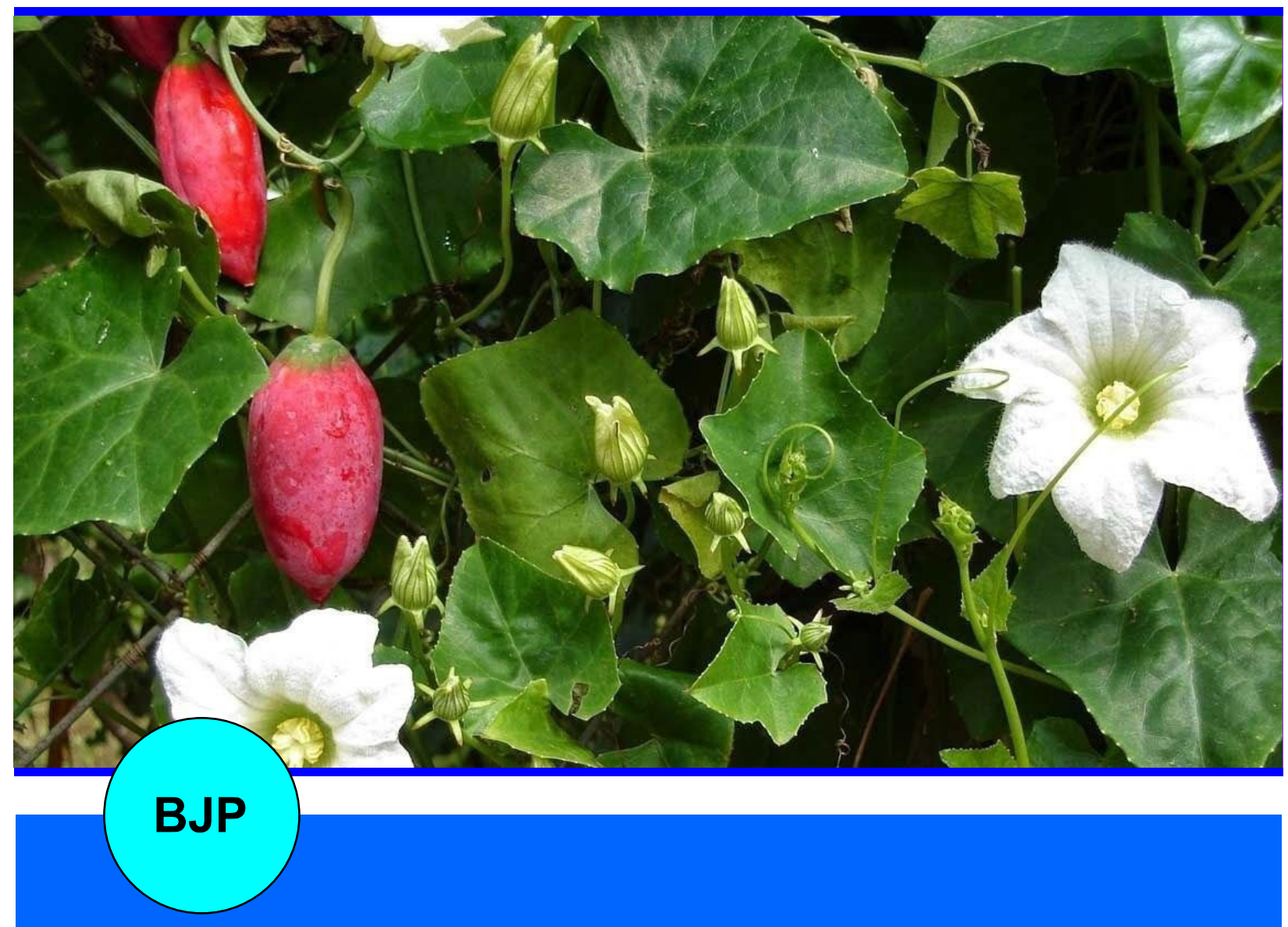

Bangladesh Journal of Pharmacology

Research Article

In vivo antitussive activity of Coccinia grandis against irritant aerosol and sulfur dioxide-induced cough model in rodents 


\title{
In vivo antitussive activity of Coccinia grandis against irritant aerosol and sulfur dioxide-induced cough model in rodents
}

\author{
Shakti Prasad Pattanayak ${ }^{1}$ and Priyashree Sunita ${ }^{2}$ \\ ${ }^{1}$ Division of Pharmacology, Birla Institute of Technology, Mesra, Ranchi 835215, India; ${ }^{2}$ Government Pharmacy In- \\ stitute, Govt. of Jharkhand, Bariatu, Ranchi 834009, India.
}

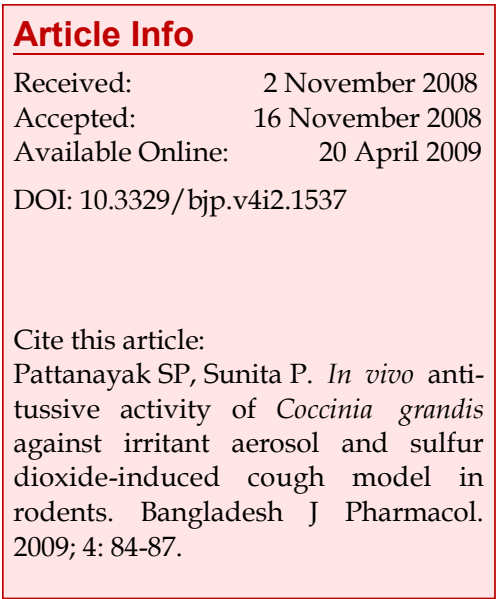

Abstract
Coccinia grandis (Cucurbitaceae) has extensively used to get relief from asthma
and cough by the indigenous people of India. The antitussive effect of
aerosols of two different concentrations $(2.5 \%, 5 \% \mathrm{w} / \mathrm{v}$ ) of methanol extract of
C. grandis fruits were tested by counting the numbers of coughs produced due
to aerosols of citric acid, $10 \mathrm{~min}$ after exposing the male guinea pigs to
aerosols of test solutions for 7 min. In another set of experiment methanol
extract was investigated for its therapeutic efficacy on cough model induced
by sulfur dioxide gas in mice. The results showed significant reduction of
cough number obtained in the presence of both concentrations of methanol
extract as that of the prototype antitussive agent codeine phosphate. Also,
methanol extract exhibited significant antitussive effect at 100,200 and 400
mg/kg, per orally by inhibiting the cough by $20.6,33.7$ and $56.7 \%$ within 90
min of performing the experiment respectively.

\section{Introduction}

Coccinia grandis Voigt. (Cucurbitaceae), commonly known as 'Little gourd' and as 'Kovai' (Hindi), is a climbing perennial herb with a tuberous rootstock producing annual stems up to several meters long, hispid.

The plant has been extensively used in Ayurvedic and Unani practice in the Indian subcontinent (Chopra et al., 1956; Varier and Sala, 1994). The entire plant is reported to use for the treatment of syphilis, sores and bacterial infections (De Boer et al., 2005). The plant also possesses potent antidiabetic (Kumar et al., 1993; Singh et al., 1985; Mukerjee et al., 1972) and anti-dyslipidemic activity (Singh et al., 2007). Indigenous people use various parts of the plant to get relief from asthma and cough (Varier and Sala., 1994). To substantiate its activity against cough and cold attack, the present study was designed to investigate the effect of $C$. grandis fruit extract on irritant aerosol-induced coughing in male guinea pigs (Forsberg et al., 1988) and sulfur dioxide- induced cough reflex in mice (Miyagoshi et al., 1986).

\section{Materials and Methods}

\section{Plant material and extraction}

The fruits of C. grandis were collected from Birla Institute of Technology, Mesra campus, Ranchi during September, 2006. The plant materials were identified by the Department of Natural Products, Regional Research Laboratory, Bhubaneswar, India. A voucher specimen [No. CNH/1-1 (44)] had been kept in our laboratory for future reference. The fruits were shade-dried, powdered, passed through a 40-mesh sieve and finally subjected to extraction with methanol in a soxhlet apparatus. The solvent was removed under vacuum and a solid mass $(15.3 \% \mathrm{w} / \mathrm{w}$ with respect to dry starting material) so obtained was stored in a desiccator and used for further experimental studies. The methanol extract of the fruit was subjected for preliminary phytochemical screening to show the 
presence of steroid, alkaloid, glycoside, tannin, triterpenoid, carbohydrates and reducing sugar.

\section{Experimental animals}

The experiments were carried out in male guinea pigs (400-450 g) and Swiss albino mice (30-40 g) of either sex. Animals were kept in the animal house at $26 \pm 2{ }^{\circ} \mathrm{C}$ at relative humidity $44-55 \%$ and light-dark cycles of 10 and 14 hours, respectively. Animals were provided with rodent diet and water ad libitum. The animal experiment was performed according to the institute's ethical committee approval and guidelines Registration No. 621/02/ac/CPCSEA of Birla Institute of Technology, Mesra, India.

\section{Protocol for irritant aerosol-induced antitussive} evaluation

Guinea pigs, five in each group, were used in the study by the method described elsewhere (Forsberg et al., 1988). Unanesthetized and unrestrained animals were placed individually in a transparent perspex chamber, dimensions $30 \times 20 \times 20 \mathrm{~cm}$ and exposed to a nebulized aqueous solution of i.e. $0.1 \mathrm{~g} / \mathrm{mL}$ of citric acid for 7 min. The aerosol was produced by airflow of $8 \mathrm{~L} / \mathrm{min}$ through a Wright nebulizer. The aerosol particles had a mass median aerodynamic diameter of $0.9 \mu \mathrm{m}$. The output of nebulizer was $0.7 \pm 0.04 \mathrm{~mL}$ solution per min and continued for $7 \mathrm{~min}$. The same nebulizer was used throughout the experiment. During the last $5 \mathrm{~min}$ of the exposure, the animals were watched continuously by a trained observer, and the numbers of coughs were determined. Coughs could easily be distinguished from sneeze since there was a clear difference in sound as well as in behavior of the animals (Forsberg et al., 1988).

The above protocol was performed $10 \mathrm{~min}$ after exposing animals to aerosols of the following solutions for a period of $7 \mathrm{~min}(n=5)$ : a) normal saline (baseline measurement); b) codeine solution $(0.03 \mathrm{~g} / \mathrm{mL}$, positive control); c) $2.5 \%$ methanol extract; d) $5 \%$ methanol extract.

All the experiments were performed randomly with 2 hours resting period between each two experiments.

\section{Sulfur dioxide-induce antitussive evaluation}

Antitussive effect against sulfur dioxide-induced cough was evaluated by the method as described by Miyagoshi et al., 1986. The experimental model is shown in Figure 1, where, $\mathrm{V}_{1}$ is $500 \mathrm{~mL}$ three-necked flask containing aqueous saturated solution of sodium hydrogen sulfite.

By opening the stopcock of a burette $V_{2}$, the concentrated sulfuric acid was introduced to generate sulfur dioxide gas. The chemical reaction that occurred in the flask $A$ is:

$2 \mathrm{NaHSO}_{3}+\mathrm{H}_{2} \mathrm{SO}_{4}=2 \mathrm{SO}_{2} \uparrow+\mathrm{Na}_{2} \mathrm{SO}_{4}+2 \mathrm{H}_{2} \mathrm{O}$
Previously, $\mathrm{SO}_{2}$ gas was filled in $\mathrm{V}_{1}$ and $\mathrm{V}_{3}$ gas reservoirs, and then by opening the cocks 3 and 2, pressure in the gas reservoir $V_{3}$ was elevated which was recorded by the water manometer $\mathrm{V}_{4}$. Then the stopcock 2 was closed and stopcock 4 was opened slightly till the pressure in $V_{4}(11 \mathrm{~mm}$ i.d.) reached $75 \mathrm{~mm}$ water, when the stopcock was closed. The procedure was operated in a draught.

The mice were divided into five groups, each containing 10 mice. One group served as a control group receiving only $2 \% \mathrm{v} / \mathrm{v}$ aqueous Tween 80 solution (10 $\mathrm{mL} / \mathrm{kg}$, per orally). Three groups were used for methanol extract of fruits $(100,200$ and $400 \mathrm{mg} / \mathrm{kg}$ per orally) and the remaining group was used for standard drug codeine phosphate $(10,20$ and $40 \mathrm{mg} / \mathrm{kg}$ per orally). Both the extract and codeine phosphate were suspended separately in $2 \% \mathrm{v} / \mathrm{v}$ aqueous Tween 80 solution. Initially, the cough responses of all groups of animals were observed $(0 \mathrm{~min})$ by placing the animals individually in a desiccator $V_{5}$. The cocks 3,6 and 5 were opened in order and when the pressure in $V_{4}$ became $0 \mathrm{~mm}$ of water, all the cocks were closed immediately. A certain amount of $\mathrm{SO}_{2}$ gas $(5 \mathrm{~mL}$ which was kept constant throughout the experiment) was introduced in the desiccator in this way. After 1 min of introduction of the gas, the mice were taken out of the desiccator and the frequency of cough was observed for $5 \mathrm{~min}$ in an open-ended filter funnel with a stethoscope at the tip in which the mice were confined. In this way the frequency of cough was observed for all animal groups at $0 \mathrm{~min}$ (before the drug administration) and at 30, 60, 90, $120 \mathrm{~min}$ interval (after the drug administration).

\section{Statistical analysis}

The frequency of cough produced by irritant-aerosol in guinea pigs were analyzed by one-way ANOVA followed by Bonferroni's multiple comparison tests to compare all pairs of columns. The results are expressed as means \pm standard error of mean (S.E.M.). The data obtained from sulfur dioxide-induced experiment were

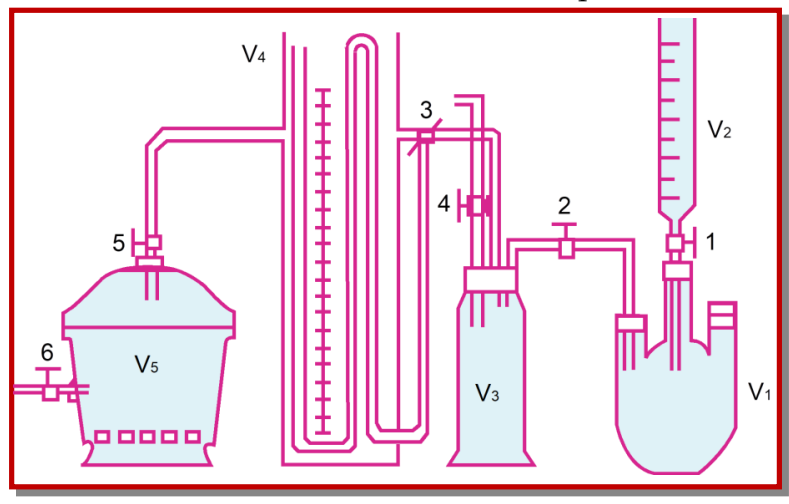

Figure 1: Apparatus for antitussive evaluation by sulfur dioxide gas production. $\mathrm{V}_{1}$ : Saturated $\mathrm{NaHSO}_{3}$ solution in $500 \mathrm{~mL}$ flask. $\mathrm{V}_{2}$ : Concentrated $\mathrm{H}_{2} \mathrm{SO}_{4}$ in burette. $\mathrm{V}_{3}$ : Gas cylinder. $\mathrm{V}_{4}$ : Water manometer. $\mathrm{V}_{5}$ : Desiccator 


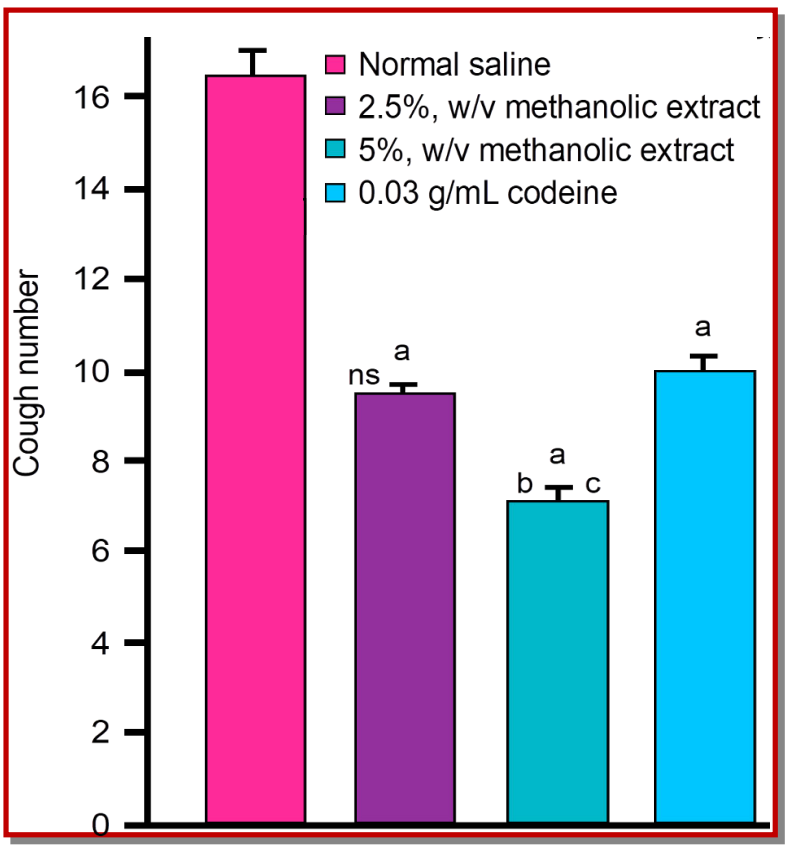

Figure 2: Cough number obtained in the presence of low $(2.5 \%, \mathrm{w} / \mathrm{v})$ and high $(5 \%, \mathrm{w} / \mathrm{v})$ concentrations of methanol extract of Coccinia grandis fruits compared to those obtained in the presence of saline (baseline) and codeine phosphate $(0.03 \mathrm{~g} / \mathrm{mL})$. Statistical differences between plant extracts, standard (codeine) with baseline values; a $p<0.001$. Statistical differences between cough number obtained in presence of plant extracts with that of codeine; ns: non significant difference, ${ }^{b} p<0.001$. Statistical difference between both the extract concentrations; ${ }^{c} \mathrm{p}<0.01$

analyzed by one-way ANOVA followed by Dunnett's test for comparing between the control group and the various groups. Statistical significance was assumed at the 0.05 levels.

\section{Results}

\section{Aerosol-induced antitussive evaluation}

In the present study the antitussive effects of extracts from C. grandis were evaluated using a standard method used previously by several investigators (Forsberg et al., 1988; Karlsson et al., 1990). The results are depicted in Figure 2. Both concentrations of methanol extract $(2.5 \%$ and $5 \%)$ and the prototype drug, codeine phosphate $(0.03 \mathrm{~g} / \mathrm{mL})$ caused significant reduction in cough number compared to base line value $(p<0.001$, Figure 2$)$. The antitussive effects $5 \%$ methanol extract also significantly greater than that of codeine $(p<0.01$, Figure 2$)$, but $2.5 \%$ methanol extract was not significant. In addition, the antitussive effects of higher concentrations of methanol extract of $C$. grandis were significantly greater than those of lower concentrations $(\mathrm{p}<0.01)$.

\section{Sulfur dioxide-induced antitussive evaluation}

The effect of C. grandis extract on sulfur dioxideinduced cough in experimental animals is shown in Table I. It was observed that on exposure of the experimental animals (mice) to sulfur dioxide gas, the frequency of cough of control group remains more or less constant, i.e. it varies between $57.6 \pm 0.2$ and $62.9 \pm$ 0.3 (mean \pm SEM). But both in case of codeine phosphate and extract of C. grandis on oral administration, frequency of cough decreased in a dose-related manner. It was found that both the standard drug and extract (at different doses) produce maximum inhibition of cough reflex at 90 min after drug administration. A dose-dependent inhibition of cough was observed with methanol extract and results were also comparable with the effect produced by codeine phosphate, a prototype antitussive agent. The results obtained with 100,200 , and $400 \mathrm{mg} / \mathrm{kg}$ doses of extract were statistically significant $(\mathrm{p}<0.01)$ throughout the time span of the experiment. The highest inhibition of cough $(56.7 \%)$ was produced by the extract of the $400 \mathrm{mg} / \mathrm{kg}$ dose level at $90 \mathrm{~min}$ of the experiment, whereas codeine phosphate $(40 \mathrm{mg} / \mathrm{kg})$ showed maximum $73.0 \%$ inhibition. The percentage inhibition of cough in codeine phosphate was $68.5-70.5 \%$ between $30 \mathrm{~min}$ to

Table I

Effects of Coccinia grandis methanol extract and codeine phosphate on the cough induced by sulfur dioxide gas in mice

\begin{tabular}{|c|c|c|c|c|c|c|}
\hline \multirow[t]{2}{*}{ Treatment } & \multirow[t]{2}{*}{ Dose } & \multicolumn{5}{|c|}{ Frequency of cough (mean \pm SEM) } \\
\hline & & $0 \mathrm{~min}$ & $30 \mathrm{~min}$ & $60 \mathrm{~min}$ & $90 \mathrm{~min}$ & $120 \mathrm{~min}$ \\
\hline Saline control & $10 \mathrm{~mL} / \mathrm{kg}$ & $60.2 \pm 0.3$ & $62.9 \pm 0.3$ & $60.3 \pm 0.5$ & $59.3 \pm 0.9$ & $57.6 \pm 0.2$ \\
\hline Codeine phosphate & $10 \mathrm{mg} / \mathrm{kg}$ & $60.9 \pm 0.3^{\mathrm{ns}}$ & $\begin{array}{r}44.2 \pm 0.6^{\mathrm{a}} \\
(29.7)\end{array}$ & $\begin{array}{r}39.5 \pm 0.6^{\mathrm{a}} \\
(34.4)\end{array}$ & $\begin{array}{r}34.7 \pm 1.2^{\mathrm{a}} \\
(41.5)\end{array}$ & $\begin{array}{r}35.6 \pm 0.4^{\mathrm{a}} \\
(38.2)\end{array}$ \\
\hline Codeine phosphate & $20 \mathrm{mg} / \mathrm{kg}$ & $60.4 \pm 0.2^{\mathrm{ns}}$ & $\begin{array}{r}32.4 \pm 0.6^{\mathrm{a}} \\
(48.5)\end{array}$ & $\begin{array}{r}25.0 \pm 0.4^{a} \\
(58.5)\end{array}$ & $\begin{array}{r}23.0 \pm 0.6^{\mathrm{a}} \\
(61.2)\end{array}$ & $\begin{array}{r}23.2 \pm 0.4^{\mathrm{a}} \\
(59.7)\end{array}$ \\
\hline Codeine phosphate & $40 \mathrm{mg} / \mathrm{kg}$ & $59.9 \pm 0.3^{\mathrm{ns}}$ & $\begin{array}{r}19.8 \pm 0.3^{a} \\
(68.5)\end{array}$ & $\begin{array}{r}16.5 \pm 0.6^{a} \\
(72.6)\end{array}$ & $\begin{array}{r}16.0 \pm 0.6^{\mathrm{a}} \\
(73.0)\end{array}$ & $\begin{array}{r}17.0 \pm 0.6^{a} \\
(70.5)\end{array}$ \\
\hline Methanol extract & $100 \mathrm{mg} / \mathrm{kg}$ & $60.1 \pm 0.2^{\mathrm{ns}}$ & $\begin{array}{r}52.4 \pm 0.5^{\mathrm{a}} \\
(16.7)\end{array}$ & $\begin{array}{r}50.5 \pm 0.3^{a} \\
(16.2)\end{array}$ & $\begin{array}{r}47.1 \pm 0.6^{a} \\
(20.6)\end{array}$ & $\begin{array}{r}53.8 \pm 0.4^{a} \\
(6.6)\end{array}$ \\
\hline Methanol extract & $200 \mathrm{mg} / \mathrm{kg}$ & $60.1 \pm 0.3^{\mathrm{ns}}$ & $\begin{array}{r}43.3 \pm 0.7 \mathrm{a} \\
(31.2)\end{array}$ & $\begin{array}{r}42.7 \pm 0.8^{a} \\
(29.0)\end{array}$ & $\begin{array}{r}39.3 \pm 0.3^{a} \\
(33.7)\end{array}$ & $\begin{array}{r}42.8 \pm 0.9 a \\
(25.7)\end{array}$ \\
\hline Methanol extract & $400 \mathrm{mg} / \mathrm{kg}$ & $60.3 \pm 0.2^{\mathrm{ns}}$ & $\begin{array}{r}30.6 \pm 0.8^{\mathrm{a}} \\
(51.4)\end{array}$ & $\begin{array}{r}32.0 \pm 0.9^{\mathrm{a}} \\
(46.9)\end{array}$ & $\begin{array}{r}25.7 \pm 0.3^{\mathrm{a}} \\
(56.7)\end{array}$ & $\begin{array}{r}30.8 \pm 0.7 \mathrm{a} \\
(46.5)\end{array}$ \\
\hline
\end{tabular}


$120 \mathrm{~min}$ at the high $(40 \mathrm{mg} / \mathrm{kg})$ concentration which was comparatively higher than other two groups (10, $20 \mathrm{mg} / \mathrm{kg}$ ) i.e. $29.7-38.2 \%, 48.5-59.7 \%$ respectively. Whereas methanol extract at $400 \mathrm{mg} / \mathrm{kg}$ caused 51.4$46.5 \%$ cough inhibition between $30-120 \mathrm{~min}$. The other two concentrations of extracts $(100,200 \mathrm{mg} / \mathrm{kg})$ inhibited $6.7-6.6 \%$ and $31.2-25.7 \%$ respectively.

\section{Discussion}

Coughing is a normal physiological response to an irritation of the laryngo-tracheo-bronchial system caused by mechanical or chemical stimulation. It may be painful and fatiguing and require suppression by antitussive drugs. In animals, coughing has been elicited by mechanical (Tedeschi et al., 1959) or chemical irritation (Turner, 1968) and by electrical stimulation (Cavanagh et al., 1976) of tracheal mucosa or by nerve stimulation (Pickering and James, 1979). Of all these methods, chemical or mechanical stimulation are more similar to the physiological event and also the experimental models generally used in man.

In the present study, the antitussive activity of methanol extract has been compared with that of codeine against coughing-induced in two different animal species by chemicals stimulation (irritant citric acid aerosol and sulphur dioxide gas) stimulation. The extracts showed marked antitussive effect. The extract showed significant inhibition of cough like the standard drug (codeine phosphate) in dose-dependent manner; thus the extract might be acting via the central nervous system, but the exact mechanism of action can not be withdrawn from the preliminary study.

\section{Conclusion}

The extract of C. grandis produced a significant antitussive effect and thus established the claim of using the plant as an anti-cough agent in ancient folklore medicine.

\section{Financial Support}

Self-funded

\section{Ethical Issue}

The study was approved by the Ethical Committee of the Birla Institute of Technology. All animal experiments were carried out according to the law of Animal Experiments Guidelines approved by National Institute of Health (NIH)

\section{Conflict of Interest}

Authors declare no conflict of interest

\section{References}

Cavanagh RL, Gylys JA, Bierwagen ME. Antitussive properties of butorphanol. Arch In Pharmacodyn. 1976; 220: 258-68.

Chopra RN, Nayar SL, Chopra IC. Glossary of Indian medicinal plants. New Delhi, Publication and Information Directorate, Council of Scientific and Industrial Research, 1956, p 77.

De Boer JKH, Anneleen K, Anders B, William M, Hedberg I, Levenfors JJ. Anti-fungal and anti-bacterial activity of some herbal remedies from Tanzania. J Ethnopharmacol. 2005; 96: 461-69.

Forsberg K, Karlsson JA, Theodorsson E, Lundberg JM, Persson CGA. Cough and bronchconstriction mediated by capsaicin sensitive sensory neurons in guinea pigs. Pulmonary Pharmacol. 1988; 1: 33-39.

Karlsson JA, Lanner AS, Persson GA. Airway opioid receptors mediate inhibition of cough and reflax bronchoconstriction in guinea pigs. J Pharmacol Exp Ther. 1990; 252: 863-68.

Kumar GP, Sudheesh S, Vijayalakshmi NR. Hypoglycemic effect of Coccinia indica: Mechanism of action. Planta Med. 1993; 59: 330-32.

Miyagoshi M, Amagaya S, Ogihara Y. Antitussive effects of 1ephedrine, amygdalin and makyokansokito (Chinese traditional medicine) using a cough model induced by sulfur dioxide gas in mice. Planta Med. 1986; 52: 275-78.

Mukerjee K, Ghosh NC, Datta T. Coccinia indica, as potential hypoglycaemic agent. Indian J Exp Biol. 1972; 10: 347-49.

Pickering RW, James GWL. The antitussive activity of a novel compound RU 20201. Drug Res. 1979; 29: 287-89.

Singh G, Gupta P, Rawat P, Puri A, Bhatia G, Maurya R. Antidyslipidemic activity of polyprenol from Coccinia grandis in high-fat diet-fed hamster model. Phytomedicine 2007; 14: 792-98.

Singh N, Singh SP, Vrat S, Misra N, Dixit KS, Kohli RP. A study on the antidiabetic activity of Coccinia indica in dogs. Indian J Med Sci. 1985; 39: 27-29.

Tedeschi RE, Tedeschi DH, Hitchens JT, Cook L, Mattis PA, Fellows EJ. A new antitussive method involving mechanical stimulation in unanesthetized dogs. J Pharmacol Exp Ther. 1959; 126: 338-44.

Turner RA. Screening methods in pharmacology. New York, Academic Press, 1968, p 128.

Umamaheswari M, Kuppusamy AK, Somasundaram A, Sivashanmugm T, Subhadradevi V, Thenvungal, KR. Xanthine oxidase inhibitory activity of some Indian medical plants. J Ethnopharmacol. 2007; 109: 547-51.

Varier PS, Sala AV. Indian medicinal plants: A compendium of 500 plants. New Delhi, Orient Longmann, 1994, p 133. 